\title{
Towards a competitive traditional market through infrastructure performance and redefinition categories: a case in Semarang city
}

\author{
Ferry Hermawan ${ }^{1, *}$, Ismiyati Ismiyati ${ }^{1}$, and Himawan Indarto $^{1}$ \\ ${ }^{1}$ Department of Civil Engineering, Diponegoro University, Prof. Sudharto, SH Street, Tembalang, \\ 50275, Indonesia
}

\begin{abstract}
The revitalization of the Indonesian Traditional Market has prolonged problems, becoming a never-ending story, particularly in public building standards in the last decade. A competitive traditional market is public need, where the affordable prices and infrastructure are the central consideration. This research aims to figure out the current condition of the Indonesian Traditional Market and the needs of future policy towards a competitive environment of the marketplace in a metropolitan city context. However, Western culture has been mixed into the current management of the Indonesian Traditional Market. The insight of the ideal traditional market for the metropolitan city, as well as Semarang, is the standard from Indonesian public market guidance and a lesson learned from other countries. This research was conducted between 2014-2017. A case study method was applied, using semistructured interviews, document investigation of Detailed Engineering Design (DED) and field observation of registered traditional markets in Semarang. The results will determine the current implementation of Traditional Market standards in Semarang. The infrastructure performance and redefinition category among marketplaces are suggested as a consideration toward the competitive traditional market on public building policy.
\end{abstract}

\section{Introduction}

The role of the traditional market is still significant to communities because it is one of the destinations of people to interact in the social environment, in terms of bargaining, shopping activity, and attending a special event in the market. Daily needs are also the reason why the traditional market affects the socio-economy of the communities [1]. Further, the component of the traditional market is not merely the transaction activity on consumable matters, but also the relationship between the customer or buyer and the market traders.

Traditional markets have been around since ancient times and still survive to this day, but their current existence has begun to decline due to poor market conditions. The community has begun to shift their shopping preference to modern markets, which are

* Corresponding author: ferry.hermawan@live.undip.ac.id 
cleaner and have a comfortable ambience compared to traditional markets in metropolitan cities, such as Jakarta, Bandung, Surabaya, Semarang, Solo and Yogyakarta [2,1]. Most of the traditional markets have a current image of being dirty, dark, muddy and leaky when raining $[3,4]$. Hence, to maintain the existence of traditional markets, revitalization is essential, with attention to the building form, the arrangement of stalls or kiosks, merchants, market infrastructure, location and accessibility of the traditional markets [5]. The unavailability of a comprehensive standard of traditional market revitalization on the basic needs of sustainable public buildings in Indonesia is considered one of the factors that causes issues related to a lack of competitiveness. Traditional markets are supposed to be the component to enforce reliable economy drivers for the people. Traditional market management should be directed to maintain the strong economy upturn and competitiveness for the long-term. A lesson learnt from the current standard of Indonesian Public market is that local government could be the party that responds to achieve the policy for competitiveness issues of public building management, including the traditional market. Therefore, this study attempts to figure out the local characteristics and to encourage local government to formulate competitive traditional market as an economic driver in the future.

\subsection{Revitalization of the Indonesian traditional market}

\subsubsection{Typology of revitalization impacts on the traditional market}

Revitalization provides impacts on the traditional market conditions, both physically and in social aspects. Physical market conditions due to revitalization generally change due to differences in design perception between planners, merchants and government [6]. Physical changes to the buildings are influencing trading activities within the traditional markets, such as building lighting, merchandise placement or kiosk zoning, or entrance access. Traditional market revitalization component often experiences the most design failure from physical aspects, such as resettlement of merchants, availability of parking areas and the effectiveness of its project execution (i.e. approval design). The most frequently encountered social aspects are kiosk and communications arrangements with merchants, and the determination of market revitalization goals. The typology of the impact of revitalization, both physical and social, can only be controlled by the role of government, which understands public building projects, and experts who have experience in traditional market management [7,1]. The revitalization experience of the KGM market becomes a role model, which, on the one hand the market is good to develop. However, on the other hand, it is also problematic when the skills of contractors or supervisory consultants are limited in every city in Indonesia [6].

\subsubsection{Success factor of traditional market revitalization}

Determining the success of revitalizing traditional markets is technically challenging. Empirically, the patterns of revitalization among traditional markets in Jakarta could be adopted as indicators. The success indicators of revitalization in Jakarta find that the skill of contractors in the process of socialization and marketing is fundamentally required [6]. As stated by the KGM market contractor in Jakarta, 'the contractor who has experience in market revitalization will get a good opportunity to the project bidding. No experience on the revitalization of the marketplace will fail in the process [6,7]

Furthermore, the implementation of the design, especially the layout of the merchant or zoning, affects the circulation of movement in the traditional market. Thus, the livelihood of the revitalized market which changes the previous condition is demonstrated by 
merchant arrangement. The kiosk arrangement can be indicated by those changes through revitalization. Market traders are the significant factor in the success of revitalization, both in the preparation stage, the construction process and post-construction. In fact, the success scale to the revitalization of traditional markets in Indonesia has not been comprehensively implemented in public building policies.

\subsection{Competitive traditional market: reality and hopes}

The ideal traditional market for people involves social interaction and 'a cheap price' as an attractive factor [1]. The decline in the number of traditional markets in Indonesia is a phenomenon of competition due to the emergence of modern markets, but it is also because of physical conditions and improper market management. The fact is, competitive traditional markets become a challenge for the government to reinvent strategy by revitalization. However, most of the traditional market revitalization has a negative connotation for changing the market system due to its 'loss of spirit'. The market environment feels like a supermarket because it is designed by modern architecture and they are missing some old merchants who bring local traditions.

Encouraging competitiveness of traditional markets is a very challenging process regarding government capabilities. It is not merely a physical matter of the building but also concerns longstanding social interactions in a place or region. Therefore, it is not necessarily the case that market revitalization can, at the same time, retain the traditional market competitiveness of the modern market. Lessons learned from the KGM case can be a reference for local decision makers to promote the public interest; the benefits built upon revitalization cannot be purely business interests or infrastructure investments. The longterm benefit of the traditional market revitalization process is a robust microeconomic system built from local wisdom and public will.

Traditional markets can generate the competitive regional income with some tourism packaging strategies, such as the floating markets in Thailand or Borough Market in London, with homemade products. The heritage building condition can also establish a competitive image of a traditional market, particularly on its historical value, such as the Leeds Market, the Market in Istanbul and some ancient cities with a background of Islamic civilization, such as Egypt and South Asia. Thus, a strategy is needed to encourage competitiveness for traditional Indonesian market starting from development policy to implementation program.

\section{Research method}

This research was conducted between 2014 and 2017. A case study method was applied using semistructured interviews, document investigation of Detailed Engineering Design (DED) and field observation of registered traditional markets in Semarang. The interview was conducted by the Market Agency, merchants, visitors and the heads of three public markets in Semarang, which were revitalized. The data on the current traditional market conditions were gathered before and after the revitalization, application of retribution system, and improvement of facilities as well as accessibility facilities in the traditional markets. Meanwhile, the secondary data to justify the previous condition of buildings in three case studies were collected from the document of Detail Engineering Drawing (DED). To figure out the capacity of the marketplaces, data on the population of merchants and number and size of the stalls were also collected. Regarding the location and lists of the registered market, the data were collected from the public market agency in Semarang. The interview was undertaken to corroborate and to fill in the incomplete data among traditional markets, through the perception of the parties residing in each case study site. All data were 
retrieved officially, using a permit, and were equipped with a consent form for each authority in the management of the registered market. The identity of all of the respondents was kept confidential for this research. The infrastructure data among registered traditional markets had been identified by a visual assessment of each location, according to the Indonesian Traditional Market Standard. The infrastructure and location assessments were used to figure out the performance indicator of competitiveness.

\section{Results and discussion}

\subsection{Infrastructure performance of the traditional market in Semarang}

The standard of infrastructure for the traditional market will contribute to public satisfaction. The physical indicator of the competitive traditional market in the case study area can be justified through the infrastructure components. In Semarang, the public market has a standard regulated by the Regional Regulation No.9/2013 in Article 19, Paragraph 4 of the Market Facility Service. Based on the field survey of infrastructure conditions in 2017 from 44 traditional markets in Semarang city, it is found that half of them are still not sufficient and the performance seems not satisfactory, as presented in Table 1.

Table 1. The current performance of traditional market infrastructure in Semarang.

\begin{tabular}{|c|c|c|c|c|c|}
\hline \multirow{2}{*}{ No } & \multirow{2}{*}{ Infrastructure components } & \multirow{2}{*}{ Availability (\%) } & \multicolumn{3}{|c|}{ Performance (\%) } \\
\cline { 4 - 6 } & Parking area & 83 & 50 & 33 & 17 \\
\hline 1 & Public toilet & 81 & 33 & 0 & 67 \\
\hline 2 & Lighting & 81 & 32 & 35 & 33 \\
\hline 3 & Electricity installation & 79 & 66 & 34 & 0 \\
\hline 4 & Prayer room & 78 & 46 & 24 & 30 \\
\hline 5 & Market agency office & 77 & 35 & 33 & 32 \\
\hline 6 & 75 & 31 & 34 & 35 \\
\hline 7 & Communal rubbish bin/ truck & 70 & 24 & 50 & 26 \\
\hline 8 & Clean water facility & 66 & 19 & 35 & 46 \\
\hline 9 & Hydrant & 61 & 63 & 0 & 37 \\
\hline 10 & Market information & 14 & 20 & 0 & 80 \\
\hline 11 & WTP/waste facility & 13 & 0 & 100 & 0 \\
\hline 12 & Loading and drop off & 8 & 0 & 100 & 0 \\
\hline 13 & Security/Guard & 8 & 0 & 100 & 0 \\
\hline 14 & Scale/ Weighing service & 2 & 0 & 100 & 0 \\
\hline 15 & Health unit & 2 & 0 & 100 & 0 \\
\hline 16 & Child Care Service & 0 & 0 & 0 & 0 \\
\hline 17 & Advertisement & 0 & 0 & 0 & 0 \\
\hline 18 & Transport/ Rent Car service & 0 & 0 & 0 \\
\hline 19 & Bank/ Cooperative & 0 & 0 & 0 \\
\hline 20 & Merchant community office & & & & \\
\hline
\end{tabular}


Table 1 shows that mediocre performance of infrastructure as the essential capital of traditional market competitiveness is still far from ideal. Of the physical aspect of a traditional market in the case of study area, it is only a third, which fulfils the standard. In addition, more than half of those parts are in poor condition. So, if traditional market conditions are to be driven more competitively, the local government should be committed to prioritizing the necessary infrastructure among the registered markets.

\subsection{The redefinition of categories among traditional market: a location perspective}

Regarding the standard revitalization of the traditional market arrangement, according to the Indonesian Public Market Standard (SNI Pasar Rakyat), the application of the zoning system among stalls and the provision of market facilities already meet the standard $[5,6,7]$. Nevertheless, facilities and market management should be upgraded because the previous condition is still not in compliance with the standards [5]. Moreover, some standards have not been mentioned in the Indonesian Standard $(S N I)$, namely regarding the width of the aisles in the traditional markets, typical and number of building floors, structuring and management of facilities, accessibility, the arrangement of street vendors and retribution system. In addition, due to location assessment, there are three categories of traditional market, as presented in Table 2 .

Table 2. The Redefinition Categories of Traditional Market in Semarang [8].

\begin{tabular}{|l|c|c|c|}
\hline \multicolumn{1}{|c|}{ Parameters } & City market & District market & Local market \\
\hline $\begin{array}{l}\text { Distance from the main } \\
\text { road (meter) }\end{array}$ & 65 & 5 & Less than 1 meter \\
\hline $\begin{array}{l}\text { Visibility from the main } \\
\text { road (meter) }\end{array}$ & 65 & 5 & Less than 1 meter \\
\hline $\begin{array}{l}\text { Location Density } \\
\text { (people/ } \mathrm{km}^{2} \text { ) }\end{array}$ & $10,000-16,000$ & $5,000-12,000$ & $900-1,800$ \\
\hline Merchant & 500 & 270 & 30 \\
\hline $\begin{array}{l}\text { Total public transport } \\
\text { trajectory (minimum) }\end{array}$ & 5 & 4 & 2 \\
\hline $\begin{array}{l}\text { Minimum entry access } \\
\text { (gate) }\end{array}$ & $\begin{array}{c}\text { Available, } \\
\text { depending on } \\
\text { visitors per day }\end{array}$ & $\begin{array}{c}\text { Available, } \\
\text { depending on } \\
\text { visitors per day }\end{array}$ & $\begin{array}{c}\text { Available but not } \\
\text { mandatory, because of } \\
\text { land-use policy }\end{array}$ \\
\hline Parking area & Up to 2 & 1 and basement & 1 \\
\hline Total level (storey) & 500 & 500 & 500 \\
\hline $\begin{array}{l}\text { Distance from modern } \\
\text { market (m) }\end{array}$ & \multicolumn{2}{|r}{} \\
\hline
\end{tabular}

\subsection{A competitive traditional market in the metropolitan city}

The market location in the urban management on Java island follows specific patterns that can be identified from some documents of the morphology of the city [9]. Santoso [9] argues that the traditional market position is part of the administrative centre structure and religious function. The market location is always related to the residence of the king or local leaders, the centre of worship and the town square. The forms of metropolitan cities in Java have concentric radial typologies (e.g. Jakarta and Semarang), although some of them (such as the cities of Solo, Bandung and Yogyakarta) tend to be a grid. 
The location of traditional markets, according to the patterns of urban development in Java, is placed in a strategic position, for example, located near the town square and mosque, or in the centre of the subdistrict or district capital. One of the advantages of traditional markets compared to the modern market is their location, which is always near the city centre and the central government $[9,10]$. The radius of the modern market to traditional market also influences the decline of potential buyers [11]. Unsurprisingly, the booming of modern markets, such as the hypermart or supermarket, causes the decrease in traditional markets in an urban area [12,10]. In line with the findings of Donofrio [13], the price of the goods sold is influenced by the distance of the prospective buyer's home to the traditional market.

Based on the characteristics of each different city in Indonesia, these will affect the pattern of arrangement of the traditional market buildings. The traditional market which has a strategic location mostly influencing the characteristic of buyers and how the market building location that based on population and road network system.

\section{Conclusions}

Traditional market competitiveness is influenced by several factors, among others, local government policies supported by parties with the traditional market management experience. The sufficient infrastructure and reconsideration of a development strategy, such as location and its characteristics and zoning of merchandise, will affect market operations. Traditional market structuring policies, including market revitalization, should be tailored to the characteristics of the service coverage area. Competitive markets should be redefined as a market that fits public needs with unique considerations through location and sufficient infrastructure.

This research was funded by RPP Scheme Project 2016-2017, Diponegoro University.

\section{References}

1. F. Hermawan, H. Indarto, I. Ismiyati, MATEC Web of Conferences, IJCAET \& ISAMPE 2017, 152, 01020 (2018)

2. P. Rufaidah, Jurnal Sosioteknologi, 14 (7), 405-408 (2008)

3. F. Fanani, F. Niswah, Publika, 1 (3), 1-11 (2013)

4. B.A.A. Nugroho, N. Herbasuki, Jurnal Fakultas Ilmu Sosial dan Ilmu Politik Universitas Diponegoro, 3, (2014)

5. G. Anggraini, D. Amalia, Final-Project, Department of Civil Engineering, Diponegoro University, Indonesia (2016)

6. F. Hermawan, PhD Thesis, Coventry University, UK (2015)

7. F. Hermawan, R. Soetanto, Proceeding ICONIC 2014, Nuremberg, Germany (2014)

8. R.M. Rizal, N.R. Alhamidi, Final-Project, Department of Civil Engineering, Diponegoro University, Indonesia (2017)

9. J. Santoso, Arsitektur-Kota Jawa, Kosmos, Kultur \& Kuasa. Jakarta (2008)

10. A.A.M.P, Paramita, A.A. Ayuningsasi, E-Jurnal EP Unud, 2 (5), 233-243 (2013)

11. H.M. Parawangsa, Manajemen Pembangunan Pasar, Jakarta (1994)

12. Semeru, Newsletter, 22/ (June 2007)

13. G. Donofrio, Journal of Planning History, 13, 136-159 (2014) 